\title{
STRUCTURE AND CHARACTERIZATION OF SOME HIGH CHEMICALLY RESISTANCE SILICATE GLASSES
}

\author{
${ }^{\#}$ H.A. ABO-MOSALLAM, S.N. SALAMA, S.M. SALMAN \\ Glass Research Department, National Research Centre, Dokki, Cairo, Egypt \\ \#E-mail: abomosallam@yahoo.com.au, abo-mosallam@hotmail.com, ha.ebrahim@nrc.sci.eg
}

Submitted: March 3, 2016; accepted July 10, 2016

\begin{abstract}
Keywords: Glasses, Structure, In vitro bioactivity, Microhardness, Density
A multi component silicate glasses based on $\mathrm{Li}_{2} \mathrm{O}-\mathrm{MgO}-\mathrm{P}_{2} \mathrm{O}_{5}-\mathrm{SiO}_{2}$ system were synthesized and modified by $\mathrm{Na}_{2} \mathrm{O} /$ $\mathrm{Li}_{2} \mathrm{O}, \mathrm{SrO} / \mathrm{MgO}$ and $\mathrm{CaO} / \mathrm{SrO}$ replacements. The prepared glasses have been characterized by X-ray Diffraction (XRD) and Fourier Transform Infrared Spectroscopy (FTIR). Additionally, bulk density, microhardness, chemical durability and in vitro bioactivity were evaluated as a function of introducing different alkali and alkaline element substitutions. For comprehension the in vitro bioactivity, the glass samples were soaking in simulated body fluid (SBF) solution at $37^{\circ} \mathrm{C}$ for 14 days. Scanning electron microscopy coupled with energy-dispersive X-ray (SEM-EDX) and (FTIR) were used to characterize forming hydroxyapatite layer produced on glass specimen surfaces. The results show that $\mathrm{Na}_{2} \mathrm{O} / \mathrm{Li}{ }_{2} \mathrm{O}, \mathrm{SrO} / \mathrm{MgO}$ and $\mathrm{CaO} / \mathrm{SrO}$ replacements led to enhance the bioactivity behavior of the glasses. The results are harmonious with a weaker network glass structure consequence of $\mathrm{Na}_{2} \mathrm{O} / \mathrm{Li}_{2} \mathrm{O}$ and $\mathrm{SrO} / \mathrm{MgO}$ replacement in the glasses. However, the glass network connectivity increased with addition of the higher charge to size ratio of $\mathrm{Ca}^{2+}$ instead of $\mathrm{Sr}^{2+}$. The prepared glass samples

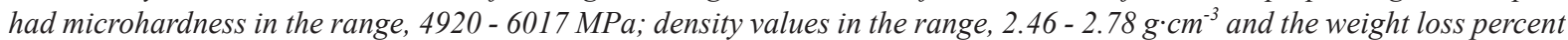
was ranged between 0.72 and $1.67 \%$.
\end{abstract}

\section{INTRODUCTION}

The bioactivity of a material is defined as the potential to form bone-like phase when implanted into bone tissue. Bioactive glass is of particular interest in orthopedic as bone substitute materials and used in dental applications [1]. The advantage of this material is that it is possible to design the glass to get controlled properties, rate of degradation and bonding to the bone. It is important to note that small changes in the composition can lead to variety of properties and this gives the chance to use a bioglass in different implantation site of the prosthesis. Composition significantly affects the bioactivity, physical and chemical properties of bioglass. The presence of network modifier cations in the glass causes a discontinuity of the glass network, which gives rise to the high reactivity of these glasses in aqueous environments. This high reactivity is a major advantage in applications in biomedicine; mainly for bone repair and replacement [2].

There are three main groups of bioactive glass divided basically on the type of former oxide in glass composition, silicate glasses; phosphate glasses; and borate glasses [3]. Silicate-based bioactive glasses are ordinarily used for biomedical applications. The limitation associated with Si-based bioactive glasses is the slow rate of degradation and conversion to apatite which further complicates the rate of implant resorption and simultaneous bone growth [4]. When the $\mathrm{SiO}_{2}$ content exceeds $60 \%$, the bioactive glass is not able to induce the formation of apatite layer even after several weeks immersion in SBF solution and it failure to bond to either bone or soft tissue [5]. The main reason is that high $\mathrm{SiO}_{2}$-containnng glasses prepared by the melt derived method lead to increase the rigidity of the glass structure and do not easily liberate alkali or alkaline cations, leading to insufficient silanol groups on the surface of glasses to motivate the apatite layer formation.

Hench et al., were the first researchers prepared silicate-based bioglass, and this material can form a chemical bond with both bone and soft tissue due to the formation of hydroxyl carbonate apatite (HCA) phase [6]. Many silicate bioactive glasses have been studied such as $45 \mathrm{~S} 5,52 \mathrm{~S}$ and $55 \mathrm{~S}$. The $45 \mathrm{~S} 5 \mathrm{Bioglass}^{\circledR}$ with the composition $\left(45 \% \mathrm{SiO}_{2}, 24.5 \% \mathrm{Na}_{2} \mathrm{O}, 24.5 \% \mathrm{CaO}\right.$, $6 \% \mathrm{P}_{2} \mathrm{O}_{5}$ in weight \%) has the highest solubility rate and exhibits excellent bioactivity enabling its application in bone regeneration and tissue engineering [7]. Many elements like Li, $\mathrm{K}, \mathrm{Mg}, \mathrm{Sr}, \mathrm{Zn}$ etc., have been incorporated into different silicate glass compositions to improve dissolution, enhance the cellular response, rate of tissue regeneration and amelioration their physical 
properties [8,9]. Lithium ions has great potential to treat bone healing and its efficiency shows that it is best candidate to incorporate in $\mathrm{CaP}$ bone in orthopaedic as bone substitute materials [10]. Lithium has many therapeutic advantages, it acts as antidepressant, it is very effectual against many kinds of microbes and can stimulate osteoblast cell activity [11]. Furthermore, lithium ions can maintain or improvement bone density [12]. Magnesium is an important element and exists in large amount in human body and exists in relatively high quantities in bone [13]. Interestingly, magnesium participate lots of biological mechanisms, such as the formation of apatite crystals [14]. The presence of magnesium in low quantity in plasma leads to the increased hazard of neurological events in patients with symptomatic peripheral artery disease [15]. Also, magnesium-containing bioglass has the ability to form a chemical bond with bone and support the growth of osteoblast-like cells [16]. Strontium element has pharmacological effects on bone when present at levels higher than those required for normal cell physiology. Besides its antiresorptive activity, strontium was found to have anabolic activity in bone. This would have significant benefits to the bone balance in normal and osteopenic animals [17]. In vitro studies strontium was found to enhance the replication of preosteoblast cells and the activity of functional cells and bone [18].

The aim of the present work is to prepare, characterize and in Vitro bioactivity study of novel high chemically resistance silicate glasses to evaluate their use as biomaterials. In order to understand the compositionproperty relationships of glass several samples were designed with varying compositions.

\section{EXPERIMENTAL}

Glass synthesis

Glass compositions were prepared based on 23.12 $\mathrm{Li}_{2} \mathrm{O}-13.28 \mathrm{MgO}-2.0 \mathrm{P}_{2} \mathrm{O}_{5}-61.6 \mathrm{SiO}_{2}$ glass system (mol. \%) with $\mathrm{Li}_{2} \mathrm{O} / \mathrm{Na}_{2} \mathrm{O}, \mathrm{SrO} / \mathrm{MgO}$ and $\mathrm{CaO} / \mathrm{SrO}$ replacements, the chemical compositions are given in Table 1. The glasses were synthesized using thoroughly mixed batches of reagent grade silica $\left(\mathrm{SiO}_{2}\right)$, lithium carbonate $\left(\mathrm{Li}_{2} \mathrm{CO}_{3}\right)$, sodium carbonate $\left(\mathrm{Na}_{2} \mathrm{CO}_{3}\right)$, magnesium carbonate $\left(\mathrm{MgCO}_{3}\right)$, calcium carbonate $\left(\mathrm{CaCO}_{3}\right)$, strontium carbonate $\left(\mathrm{SrCO}_{3}\right)$ and ammonium dihydrogen phosphate $\left(\mathrm{NH}_{4} \mathrm{H}_{2} \mathrm{PO}_{4},\right)$ powders. The powders were mixed for $30 \mathrm{~min}$ and the resulting mixture was transferred in a platinum rhodium ( $\mathrm{Pt}, 2 \% \mathrm{Rh})$ crucible. The crucible was then placed in an electric furnace (Vecastar, United Kingdom) for a period of 1.5 hours at a temperature of $1300-1350^{\circ} \mathrm{C}$ depending on the batch composition. The molten glass produced was poured into pre-heated stainless steel mold, annealed for 1 hour at $500^{\circ} \mathrm{C}$ and allowed to cool to room temperature overnight to relieve stresses in a carbolite muffle furnace.
Table 1. The composition the investigated glasses.

\begin{tabular}{cccccccc}
\hline \multirow{2}{*}{ Sample } & \multicolumn{7}{c}{ Composition Mole \% } \\
\cline { 2 - 8 } & $\mathrm{Li}_{2} \mathrm{O}$ & $\mathrm{Na}_{2} \mathrm{O}$ & $\mathrm{MgO}$ & $\mathrm{SrO}$ & $\mathrm{CaO}$ & $\mathrm{P}_{2} \mathrm{O}_{5}$ & $\mathrm{SiO}_{2}$ \\
\hline $\mathrm{G} 1$ & 23.12 & - & 13.28 & - & - & 2.0 & 61.60 \\
$\mathrm{G} 2$ & 11.56 & 11.56 & 13.28 & - & - & 2.0 & 61.60 \\
$\mathrm{G} 3$ & - & 23.12 & 13.28 & - & - & 2.0 & 61.60 \\
$\mathrm{G} 4$ & - & 23.12 & 6.64 & 6.64 & - & 2.0 & 61.60 \\
$\mathrm{G} 5$ & - & 23.12 & - & 13.28 & - & 2.0 & 61.60 \\
$\mathrm{G} 6$ & - & 23.12 & - & 6.64 & 6.64 & 2.0 & 61.60 \\
\hline
\end{tabular}

$\mathrm{X}$-Ray analysis

X-Ray Diffraction (XRD) was used to show that all glasses synthesized were completely amorphous prior to characterized. The (XRD) data was recorded with a Panalytical X-Ray Diffractometer (PW1080, Panalytical, Netherlands) using $\mathrm{Ni}$ filtered $\mathrm{Cu} \mathrm{Ka}$ radiation $(\lambda=$ $1.5406 \AA$ ), an anode current of $30 \mathrm{~mA}$ and a voltage of $40 \mathrm{k}_{\mathrm{V}}$. Diffraction patterns were collected between 5 and $70^{\circ} \mathrm{C}$ 2-theta.

\section{Fourier Transform Infra-Red Spectroscopy (FTIR)}

Fourier Transform Infra-Red Spectroscopy (FTIR) is a technique with which information about the functional groups of a material were identified at room temperature in the frequency range of $400-4000 \mathrm{~cm}^{-1}$ with a resolution of a $0.2 \mathrm{~cm}^{-1}$ using infrared spectrophotometer (JASCO, FTIR-300E, Japan). About $10 \mathrm{mg}$ of the glass powder was mixed with $200 \mathrm{mg}$ of $\mathrm{KBr}$, which had been used as a background scan material, and introduced into the FTIR spectroscopy.

\section{Density measurements}

The bulk density of the glass samples were measured at room temperature using standard Archimedes' principle with distilled water as immersion liquid. Five different pieces rods for each glass sample free from bubbles and inclusions were used during the casting process. The relative weights of glass rod samples in air and in distilled water were measured using an electrical digital balance with an accuracy of $\pm 0.1 \mathrm{mg}$. The densities were calculated using the equation below:

$$
\rho=\rho_{w}(T) \cdot W_{s} /\left(W_{s}-W_{w}\right)
$$

where: $\rho$ is the sample density $\left(\mathrm{g} \cdot \mathrm{cm}^{-3}\right), \rho_{w}(T)$ is the density of water at the measured temperature $\left(\mathrm{g} \cdot \mathrm{cm}^{-3}\right)$, $W_{s}$ is the sample weight in air $(\mathrm{g})$ and $W_{w}$ is the sample weight in water $(\mathrm{g})$.

\section{Microhardness measurements}

Microhardness tests were carried out on well-polished glass samples using a Vicker's microhardness tester (Shimadzu, Type-HMV, Japan). A load of $100 \mathrm{~g}$ 
was applied to the sample for $15 \mathrm{Sec}$. The measurements were carried out under normal atmospheric conditions. The resulting indentation diagonals were measured and the hardness was calculated using the following equation: The microhardness values are converted from $\mathrm{kg} \cdot \mathrm{mm}^{-2}$ to $\mathrm{MPa}$ by multiplying with a constant value 9.8 .

$$
H_{V}=1.854 \cdot\left(P / d^{2}\right)\left[\mathrm{kg} \mathrm{mm}{ }^{2}\right]
$$

where: $H_{V}$ is the Vickers hardness, $P$ is the applied load $(\mathrm{g}), d$ is the average diagonal length $(\mu \mathrm{m})$.

\section{Chemical durability measurements}

In the present work, the powder glass samples for durability testing were prepared and measured. Based on the procedure, the glasses were crushed in an agate mortar and then sieved to achieve the recommended particle size between 0.60 and $0.32 \mathrm{~mm}[19,20]$. The sieved glass particles were ultrasonically washed with ethyl alcohol three times, then dried in the oven $2 \mathrm{~h}$ at $120^{\circ} \mathrm{C}$. About one gram of the dried glass particles of the tested sample was accurately weighed in a sintered glass crucible of the $G_{4}$ type which was placed into a polyethylene beaker $(300 \mathrm{ml})$. The samples were tested for their chemical durability in distilled water; $200 \mathrm{ml}$ of water were introduced into the polyethylene beaker. The polyethylene beaker with its contents was covered by polyethylene cover to reduce evaporation. The chemical durability was expressed as the weight loss percent. The experiments were carried out at $95^{\circ} \mathrm{C}$ for $1 \mathrm{~h}$ to the different glass samples. The sintered glass crucible was then transferred and kept in an oven at $120^{\circ} \mathrm{C}$ for $1 \mathrm{~h}$, then cooled in a desiccator for $30 \mathrm{~min}$. After cooling, the glass crucible was reweighed and the total weight loss of the glass grains was calculated.

\section{Bioactivity in simulated body fluid (SBF)}

The bioactivity behaviour of selected glass compositions in the simulated body fluid was studied by in vitro tests. To determine the bioactivity of the glass powders, it was subjected to in vitro testing using SBF solution. About $0.075 \mathrm{~g}$ powders were soaked in $50 \mathrm{~cm}^{3}$ of $\mathrm{SBF}$ at $37^{\circ} \mathrm{C}$ and $\mathrm{pH} 7.4$. The soaked samples were placed in an incubator at a constant temperature of $37^{\circ} \mathrm{C}$ for time periods 14 days. The preparation of SBF solution was carried out according to Kokubo et al., [21]. The Tris-buffered SBF composition is $\left(\mathrm{Na}^{+} 142.0\right.$, $\mathrm{K}^{+}$5.0, $\mathrm{Mg}^{2+} 1.5, \mathrm{Ca}^{2+}$ 2.5, $\mathrm{Cl}^{-}$147.8, $\mathrm{HCO}^{3-}$ 5.0, $\mathrm{HPO}_{4}{ }^{2-} 1.0$ and $\mathrm{SO}_{4}{ }^{2-} 0.5 \mathrm{~mol} \mathrm{~m}{ }^{-3}$ ). After soaking for 14 days the glass powders were removed from the SBF solusion using filter paper $(1 \mu \mathrm{m})$, gently washed with acetone, and dried at room temperature. The filtered glass powders were analyzed by SEM-EDX and FTIR to detect the appearance of hydroxycarbonate apatite
(HCA) layer. The surface morphology of glass samples was analyzed after immersed into SBF solution for 14 days at $37^{\circ} \mathrm{C}$ using a scanning electron microscopy operating at an accelerating voltage of $30 \mathrm{kV}$, equipped with an energy dispersive spectroscopy analysis (SEM-EDX) (Quanta FEG 250, Netherlands). This technique was used to investigate the surface morphology and elemental composition of the surfaces of glass materials after soaking in the SBF solution. FTIR also can be successively used to determine the formation of a layer rich in calcium phosphate using infrared spectrophotometer (JASCO, FTIR-300E, Japan) in the frequency range of $400-4000 \mathrm{~cm}^{-1}$. The changes in $\mathrm{pH}$ of the $\mathrm{SBF}$ solution as a function of time were monitored using a $\mathrm{pH}$ meter (Jenway $350 \mathrm{pH}$ meter, UK).

\section{RESULTS AND DISCUSSION}

\section{Glass characterization}

Figure 1 shows the XRD spectra for all the prepared glasses during this study. All glasses exhibit a broad halo appeared between $20^{\circ}$ and $30^{\circ}$ (20) confirms the absence of any crystalline phase and a fully amorphous state was detected.

Fourier transform infrared spectroscopy (FTIR) is a sensitive technique to the local structure of silicate glasses. It determines the types of chemical bonds, hence structural units present in the glasses. Thus it is possible to determine any changes in the $\mathrm{Si}-\mathrm{O}-\mathrm{Si}$ vibrational modes and elicit useful information about the molecular structure of the glass. This technique is also sensitive to vibrations associated with non-bridging oxygen so it is useful when studying the glass structure following the glass network connectivity model [22]. Figure 2 shows the FTIR transmittance spectra of the prepared glass samples. The FTIR spectra of the glass samples $\mathrm{G}_{1}-\mathrm{G}_{3}$ exhibited some infrared bands located at around 427 , 468, 788, 940, 1040, 1620, 2845, 2920 and $3440 \mathrm{~cm}^{-1}$.

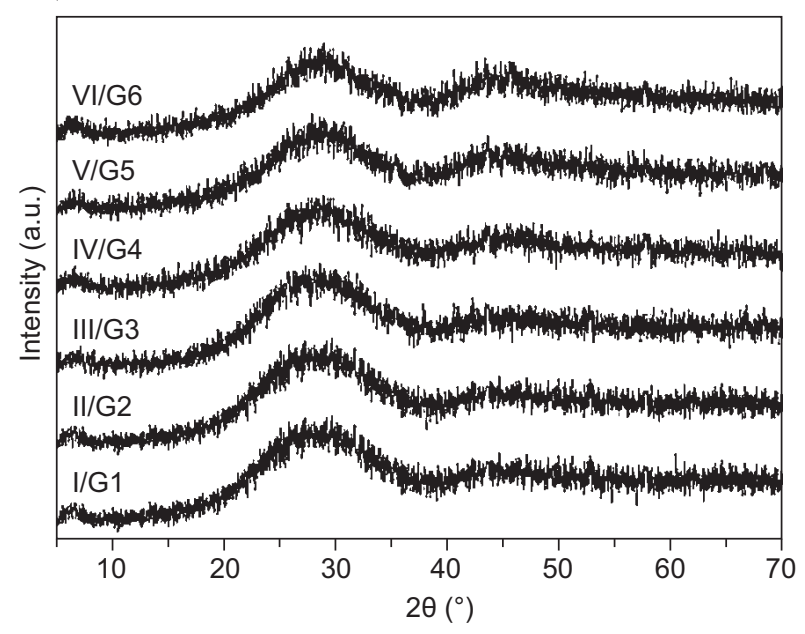

Figure 1. XRD patterns of the prepared glasses. 
The main characteristic bands ranging from 400 to $1400 \mathrm{~cm}^{-1}$ are related to the silicate network group vibrations with different bonding arrangements silicate. While, the spectra from 1400 to $4000 \mathrm{~cm}^{-1}$ clearly consists of vibrations refer to water or hydroxyl groups [23]. The spectrum located at around $427 \mathrm{~cm}^{-1}$ is ascribed to the $\mathrm{Si}-\mathrm{O}$ symmetric stretching of bridging oxygen atoms between tetrahedrons [24]. The spectrum at $468 \mathrm{~cm}^{-1}$ situated in the range $463-498 \mathrm{~cm}^{-1}$ is attributed to $\mathrm{Si}-\mathrm{O}-\mathrm{Si}$ bending vibration mode [25]. The spectra of the FTIR also shows band at around $788 \mathrm{~cm}^{-1}$ which is assigned to $\mathrm{Si}-\mathrm{O}-\mathrm{Si}$ symmetric stretching vibration of bridging oxygen between tetrahedral [26]. The bands at the $800-1200 \mathrm{~cm}^{-1}$ are assigned to the stretching vibration of the $\mathrm{SiO}_{4}$ tetrahedra with the different number of bridging oxygen atoms. Si-O-NBO (1 nonbridging oxygen per $\mathrm{SiO}_{4}$ tetrahedron, corresponding to a $Q^{3}$ structure) situated in the range $890-975 \mathrm{~cm}^{-1}$ [27]. According to that the bands presented at 940 and 1040 $\mathrm{cm}^{-1}$ are assigned to three-dimensional network structure i.e. $\mathrm{Si}-\mathrm{O}$ with one non-bridging oxygen $(\mathrm{Si}-\mathrm{O}-\mathrm{NBO})$ per $\mathrm{SiO}_{4}$ tetrahedron stretching vibration $\mathrm{Q}^{3}$ structure. The band at around $1620 \mathrm{~cm}^{-1}$ is assigned to hydroxylrelated band. While those observed at 2845 and $2920 \mathrm{~cm}^{-1}$ are related to asymmetric and symmetric stretching modes of interstitial $\mathrm{H}_{2} \mathrm{O}$ molecules. Whilst the spectrum

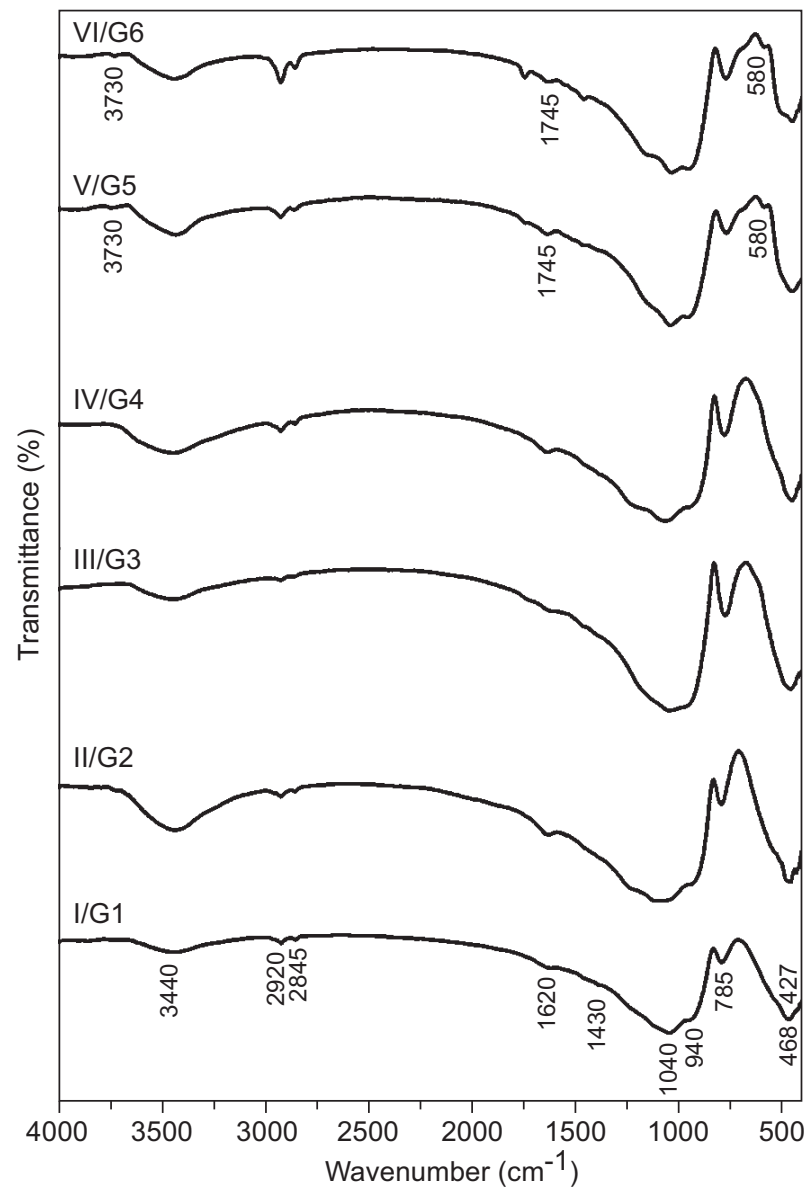

Figure 2. FTIR spectra of the prepared glass samples. around $3440 \mathrm{~cm}^{-1}$ is assigned to stretching vibrations of $\mathrm{OH}$, molecular water or $\mathrm{Si}-\mathrm{OH}$ [26].

The influence of $\mathrm{SrO} / \mathrm{MgO}$ replacements on FTIR spectrum i.e. $G_{4}$ and $G_{5}$ glass samples are shown in Figure 2 patterns IV and $\mathrm{V}$ respectively. At high $\mathrm{SrO}$ addition instead of $\mathrm{MgO}$ (i.e $\mathrm{G}_{5}$ ), the FTIR analysis (Figure 2, Pattern V) revealed that new spectra at 580, 1743 and $3731 \mathrm{~cm}^{-1}$ were detected. The band appeared around $580 \mathrm{~cm}^{-1}$ are corresponding to bending $\mathrm{P}-\mathrm{O}$ bending vibrations [28]. The spectra at 1743 and 3731 are referred to water or hydroxyl groups [23]. This may be due to increase the hygroscopic properties of the glass samples by addition of $\mathrm{SrO}$ instead of $\mathrm{MgO}$. Addition of calcium instead of strontium i.e. $\mathrm{G}_{6}$ did not detected any structural changes in the glass network. Therefore, it would be very difficult for FTIR to detect any chemical bonds vividly. This may be attributed to the mixture of $\mathrm{Ca}^{2+}$ and $\mathrm{Sr}^{2+}$ ions in glasses form a solid solution owing to their similar lattice parameter. Xiang et al., [29] reported that the $\mathrm{SrO} / \mathrm{CaO}$ substitution, have similar glass structure as compared to the original composition due to chemical resemblance of $\mathrm{Sr}^{2+}$ and $\mathrm{Ca}^{2+}$ ions.

\section{Glass properties}

Density measurements have been widely used to study the effects of composition on glass structure. The glass density depends mainly on network compactness, the change in geometrical arrangement, cross-link density and molar mass of elements [30]. The effect of different alkali and alkaline element replacements on the glass densities are presented in Figure 3. The addition of $\mathrm{Na}_{2} \mathrm{O}$ instead of $\mathrm{Li}_{2} \mathrm{O}$ led to increase the density from 2.463 to $2.487 \mathrm{~g} \cdot \mathrm{cm}^{-3}$ for $\mathrm{G}_{1}$ to $\mathrm{G}_{3}$ glasses. This may be attributed to the molar mass of $\mathrm{Li}\left(6.941 \mathrm{~g} \cdot \mathrm{mol}^{-1}\right)$ which is lower than that of molar mass of $\mathrm{Na}\left(22.989 \mathrm{~g} \cdot \mathrm{mol}^{-1}\right)$. From another perspective the $\mathrm{Na}_{2} \mathrm{O}\left(2.27 \mathrm{~g} \cdot \mathrm{cm}^{-3}\right)$ has large density than $\mathrm{Li}_{2} \mathrm{O}\left(2.01 \mathrm{~g} \cdot \mathrm{cm}^{-3}\right)$ and this leads to increase the density as the quantity of $\mathrm{Na}_{2} \mathrm{O}$ increases [31]. The effect of addition $\mathrm{SrO}$ at the expense of $\mathrm{MgO}$ on the density of the glasses show that introducing $\mathrm{SrO}$ into the glass causes an increase in density. This may

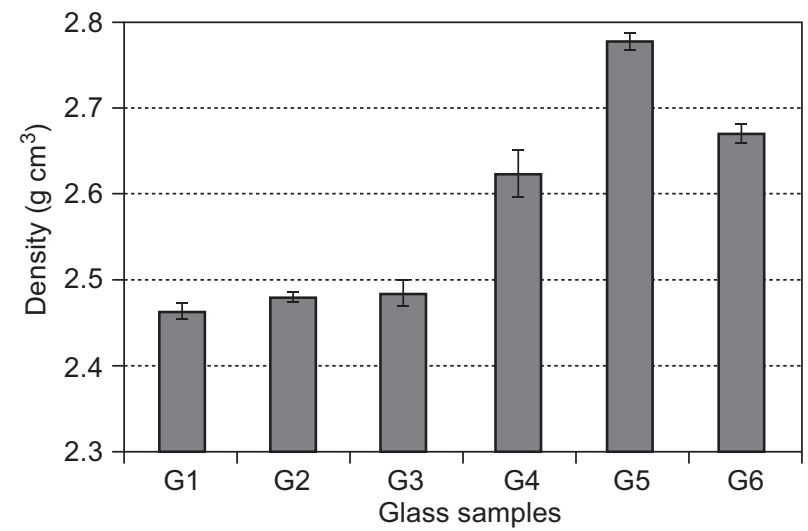

Figure 3. Density of the glass samples. 
be due to the higher density of $\mathrm{SrO}\left(4.7 \mathrm{~g} \cdot \mathrm{cm}^{-3}\right)$ than that of $\mathrm{MgO}\left(3.58 \mathrm{~g} \cdot \mathrm{cm}^{-3}\right)$ [31]. As $\mathrm{CaO}$ with molar mass $\left(56.08 \mathrm{~g} \cdot \mathrm{mol}^{-1}\right)$ is systematically substituted for $\mathrm{SrO}$ with molar mass $\left(103.62 \mathrm{~g} \cdot \mathrm{mol}^{-1}\right)$ i.e. $\mathrm{G}_{6}$ overall weight of glass decreases, thereby decreasing the density of the glass. Du and Xiang [32] reported that the $\mathrm{CaO} / \mathrm{SrO}$ substitution leads to a decrease of glass density indicating a more shrunken glass network.

The hardness is very important properties for a material it can be measure its structural compactness. The effect of different cation replacements on the glass hardness is graphically represented in (Figure 4). The substitution of $\mathrm{Li}_{2} \mathrm{O}$ by $\mathrm{Na}_{2} \mathrm{O}$ at constant magnesium and silica content generally decreased the microhardness values of the glass samples as compared with that free of $\mathrm{Na}_{2} \mathrm{O}$ (i.e. $\mathrm{G}_{1}$ ). The reduction in microhardness may be related to the decrease in glass network coherence as a result of the replacement process. As shown $\mathrm{Li}^{+}$ has a cationic field strength of $0.26 \AA^{-2}$ while $\mathrm{Na}^{+}$has a cationic field strength of $0.18 \AA^{-2}$ [33]. The decrease in glass network connectivity and compactness by $\mathrm{Na}_{2} \mathrm{O} / \mathrm{Li}_{2} \mathrm{O}$ replacement allows the glass to have a more open structure, thereby resulting in a soft material with low microhardness. The microhardness data (Figure 4) indicated also that the addition of $\mathrm{SrO}$ at the expense of $\mathrm{MgO}$ i.e. $\mathrm{G}_{3}$ and $\mathrm{G}_{4}$ led to decrease the microhardness values. This may be due to $\mathrm{Sr}^{2+}$ possess lower cationic field strength $\left(0.29 \AA^{-2}\right)$ than that of $\mathrm{Mg}^{2+}\left(0.46 \AA^{-2}\right)$ in octahedral coordination [34]. This may explain the decrease of the coherency of glass network, which leads to reduce of microhardness values. On the other hand, the glass microhardness progressively enhanced by the addition of $\mathrm{CaO}$ instead of $\mathrm{SrO}$ in the glasses. This may be attributed to the fact that decreases the disruption of the glass network by the slightly smaller calcium cation, and due to the stronger calcium-oxygen bond strength as compared with strontium-oxygen bond [35]. Obviously it is clear that the cation with the highest field strength resulted in the glass with the highest microhardness. As shown $\mathrm{Ca}^{2+}$ has a high cationic field strength $0.36 \AA^{-2}$ compared with $\mathrm{Sr}^{2+}$, which owns cationic field strength

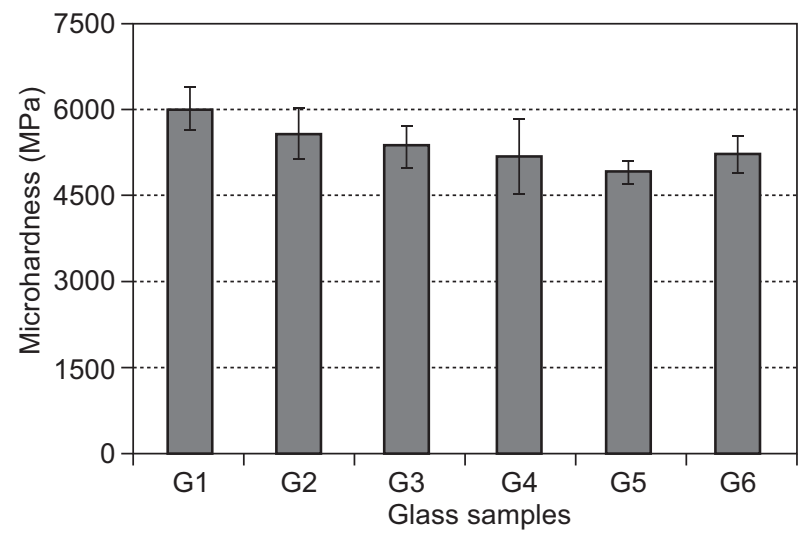

Figure 4. Microhardness of the investigated glass samples.
$0.29 \AA^{-2}[33]$, this may be explain the increase of hardness in the glass by $\mathrm{CaO} / \mathrm{SrO}$ replacement.

The dissolution of glasses is one key determines their applications in different environments and is therefore considerable significance. The dissolution sequences of the glasses vary with the composition, surface area, structure of the glass, nature and contribution of the different cations, $\mathrm{pH}$ of the solution, etc. [36]. The chemical durability results of the investigated glasses are presented in Figure 5. It is clear that in the studied glasses, the dissolution is increased with increasing the content of sodium instead of lithium. An explanation for the increased solubility of glasses may be due difference in atomic sizes of lithium and sodium. The size of a lithium atom is $1.67 \AA$ whereas the size of a sodium atom is $1.90 \AA$ [37]. When the smaller lithium atoms are present in the network, the glass tends to be more stable. As it is replaced with the larger sodium atoms, it is possible that resulting in a more loosely glass network structure and causing the glass to be becomes more reactive with the solutions. In the same context, the decrease in chemical durability of the glasses as $\mathrm{SrO}$ is substituted for $\mathrm{MgO}$ may be due to the different degrees of network disruption by those alkaline earth ions considered. The decrease in durability as $\mathrm{Sr}^{2+}$ ion content increases implies that the strength of the glass structure is weakened. Avramov et al., [38] reported that the larger cations are, the greater the restriction on disrupting the glass networks. Substitution of $\mathrm{SrO}$ with atom size $[2.19 \AA]$ for $\mathrm{MgO}[1.45 \AA]$ in the glasses will result in weaken the coherence of glass structure. While, the positive linear relationship between chemical durability and $\mathrm{CaO} / \mathrm{SrO}$ replacement in the glass indicates that the glass network structure is strengthened. This suggests that introducing a relatively small calcium atom size $[1.94 \AA]$ instead of strontium atom size [2.19 $\AA]$ leads

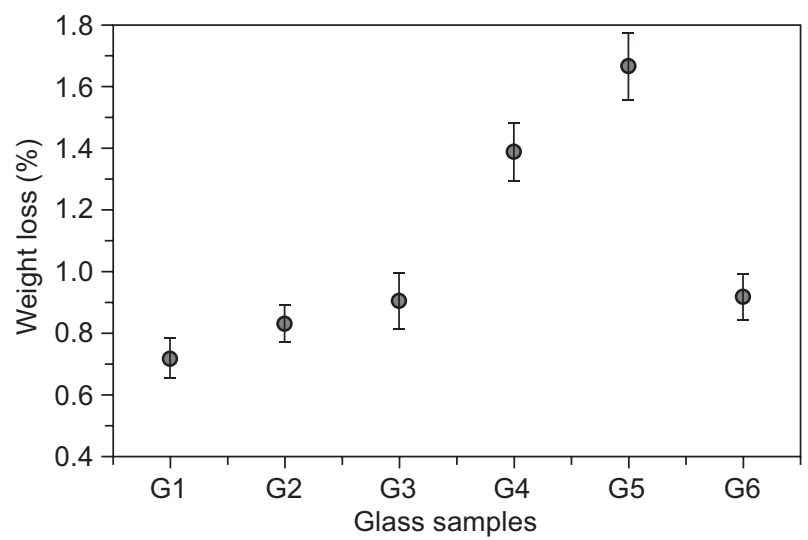

Figure 5. Chemical durability of the glass samples.

to an increase of cross-linking in the glass structure and enhancement the chemical durability of the glasses.

A glass is believed to be bioactive if a calcia-phosphate $(\mathrm{CaP})$ layer is formed on its surface. This bioactivity 
depends strongly on glass compositions and its structure. The more open glass network structure results in faster glass degradation, consequently precipitation of apatite because more ions can readily travel, thereby increasing the ion exchange rate [39]. Apatite formation is also strongly dependent on $\mathrm{pH}$ whether in vivo or in vitro tests. The change in $\mathrm{pH}$ of $\mathrm{SBF}$ solution is taken as a measure of glass samples dissolution and bioactivity. The variation of the $\mathrm{pH}$ of SBF solution after immersion at different time durations has been clearly seen from Figure 6. With each of the glass composition the initial dissolution kinetics of the different glass compositions does not change, but the overall $\mathrm{pH}$ change increases with decreasing network connectivity. The results showed that there was a slight raised in the $\mathrm{pH}$ values along the inundation time until 14 days. The maximum $\mathrm{pH}$ values were recorded in all the samples after 14 days immersion compared with the initial $\mathrm{pH}$ of the SBF solution $(\mathrm{pH}=7.4)$. The $\mathrm{pH}$ values on fourteen days were measured as $\mathrm{pH}=7.71,7.75,7.78$, and 7.89 for the glass samples $G_{1}, G_{3}, G_{5}$ and $G_{6}$ respectively. The increase in $\mathrm{pH}$ with the immersion time for all samples may be attributed to ionic exchange between soluble cations in the glass composition like $\mathrm{Li}^{+}, \mathrm{Na}^{+} \mathrm{Ca}^{2+}, \mathrm{Mg}^{2+}$ and $\mathrm{Sr}^{2+}$ with $\mathrm{H}^{+}$or $\mathrm{H}_{3} \mathrm{O}^{+}$in $\mathrm{SBF}$ solution. Therefore, this ionic exchange led to the boost in hydroxyl amount of the solution which led to offensive in silicate glass network and formation of silanols groups [40]. The results also showed that the base glass composition i.e. $\mathrm{G}_{1}$ exhibit the low $\mathrm{pH}$ value compared with the other glass specimens. This may be due to increase the durability of glass by increasing the $\mathrm{Mg}$ content. By increasing the $\mathrm{Mg}$ content in the glasses, it leads to the formation of more

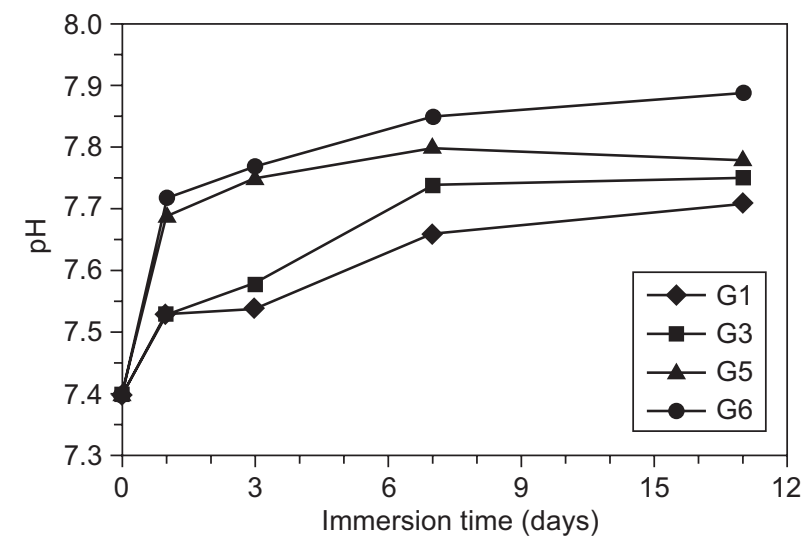

Figure 6. $\mathrm{pH}$ changes of SBF solutions after immersion of samples for 14 days.

bridging-oxygens within the glass network, as well as big tetrahedral angle values [41].

The SEM micrographs showed that the surface of glass specimen $G_{1}$ after the immersion for 14 days in the SBF solution was free of apatite layer (Figure 7). That's which has been clearly proven from EDX analysis by disappearance of calcium and phosphorous peaks and existence of high intensity peaks of silica and oxygen. This result agrees with the sequence of surface reactions of bioactive glass mechanism suggested by Hench from stage I up to stage III [42] i.e.,

(i) Rapid cation exchange of $\mathrm{Na}^{+}$and $\mathrm{Ca}^{2+}$ in the glass with formation of $\mathrm{H}^{+}$or $\mathrm{H}_{3} \mathrm{O}^{+}$from the aqueous solution, creating silanols $\left(\mathrm{Si}-\mathrm{OH}^{+}\right)$within the glass:

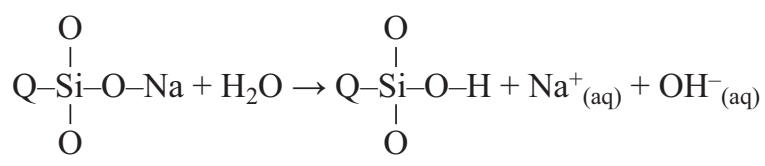

(ii) The cation exchange increases the hydroxyl $\left(\mathrm{OH}^{-}\right)$ concentration of the solution, which leads to an attack on the silica glass network:

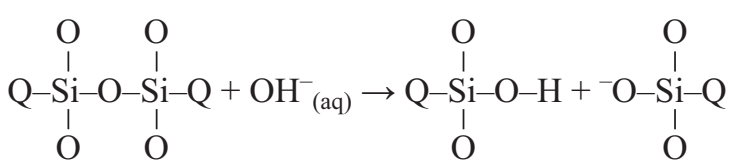

Soluble silica is lost to the solution in the form of $\mathrm{Si}(\mathrm{OH})_{4}$, resulting from this breaking of $\mathrm{Si}-\mathrm{O}-\mathrm{Si}$ bonds and the continued formation of silanols at the glass-solution interface.

(iii) Condensation and repolymerization creates a silica $\left(\mathrm{SiO}_{2}\right)$ rich surface layer, depleted in alkalis (e.g. $\mathrm{Li}^{+}, \mathrm{Na}^{+}, \mathrm{K}^{+}$) and alkaline-earth cations (e.g. $\mathrm{Ca}^{2+}$ ).

The addition of $\mathrm{Na}_{2} \mathrm{O}$ at the expense of $\mathrm{Li}_{2} \mathrm{O}$ led to slightly improve the bioactivity of the glass sample. The SEM micrograph of the glass sample $\mathrm{G}_{3}$ Figure 7 showed precipitates fine crystals of calcium phosphate layer. This finding was supported by another proof to confirm the formation of apatite phase on the surfaces of $\mathrm{G}_{3}$ glass specimen, which was sought by using the EDX techniques. The EDX analysis revealed that peaks of calcium and phosphorous were depicted alongside with sodium, magnesium and chlorine peaks attributed to apatite formation. In the SEM micrographs corresponding to $G_{5}$ and $G_{6}$ after 14 days of soaking in SBF solution it is clearly proves formation of apatite layer. The results also confirm that $\mathrm{CaO} / \mathrm{SrO}$ replacement induced formation of this layer as shown in (Figure 7). The Si/P ratio observed in EDX spectra of specimen $\mathrm{G}_{6}$ as compared with the sample $\mathrm{G}_{5}$ refers the formation of apatite layer higher thickness this means that a higher amount of $\mathrm{Ca}-\mathrm{P}$ layer is precipitated (Figure 7). This result is consistent to the findings of the Hesaraki et al., [9] they reported that the substitution of $\mathrm{Ca}$ for $\mathrm{Sr}$ in the glass composition promotes formation of apatite layer onto the glass surfaces.

FTIR can be used to determine the bioactivity of a glass by analyzing the peak locations appeared on the spectrum, thereby identifying the corresponding chemical bonds. When bioactive glasses are exposed to 
body fluids, they undergo corrosion by the leaching of alkali ions resulting in the formation of a silica gel and a layer rich in calcium phosphate. Successively, the calcium phosphate layer crystallizes to form hydroxyapatite [3]. Figure 8 shows the FTIR spectra of the glasses powder before and after soaking in SBF solution for 14 days. The FTIR of $\mathrm{G}_{1}$ after immersion in SBF solution show sharpening of the $\mathrm{Si}-\mathrm{O}-\mathrm{Si}$ bending peak at $468 \mathrm{~cm}^{-1}$ [41], formation of $\mathrm{Si}-\mathrm{O}-\mathrm{Si}$ (tetrahedral) peak at $790 \mathrm{~cm}^{-1}$, the peak of $\mathrm{Si}-\mathrm{O}$ stretching (2NBO)
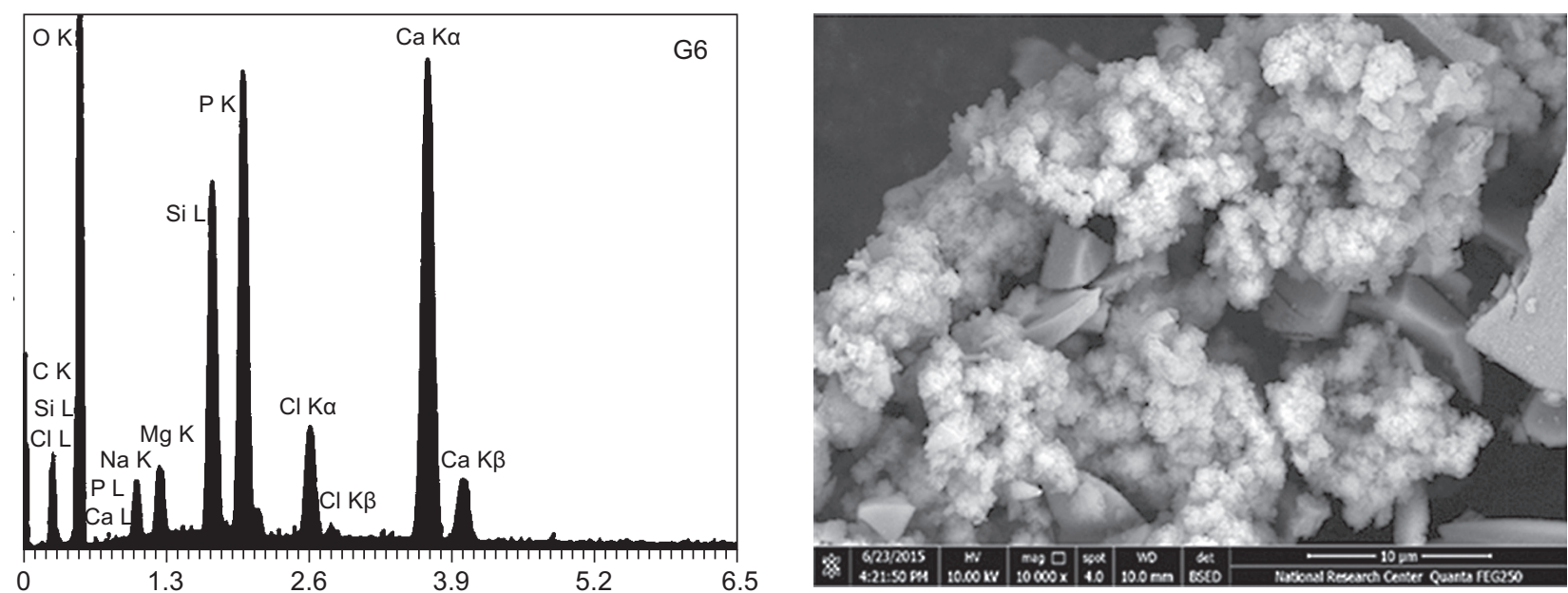

a)
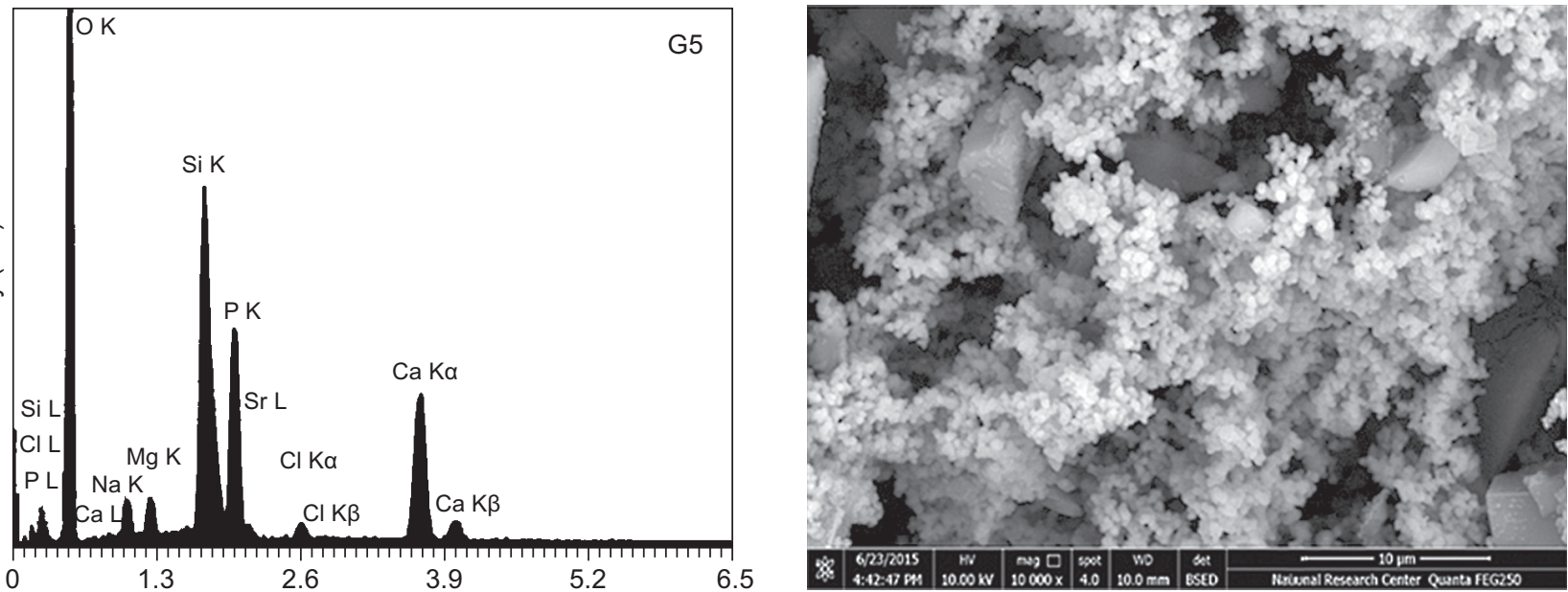

b)
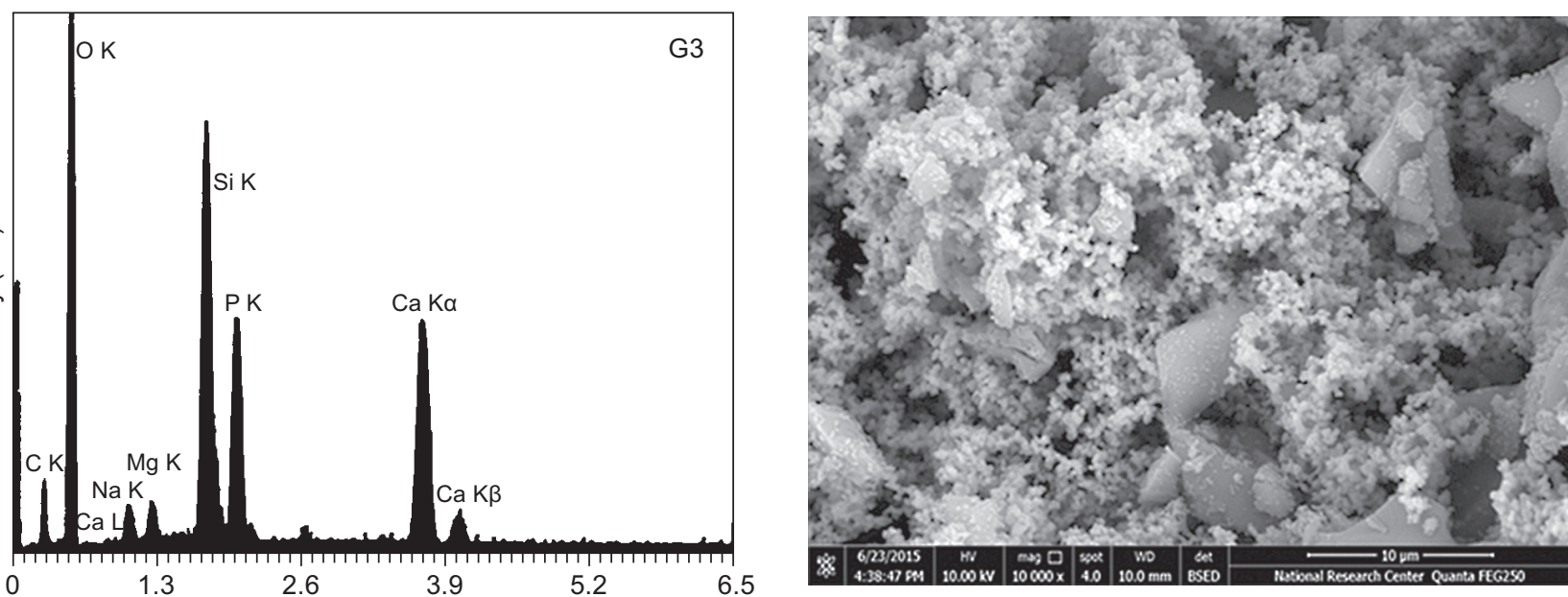

c)

Figure 7. SEM Micrographs and EDX spectra of the glasses after immersion in SBF solution for 14 days. (Continue on next page) 


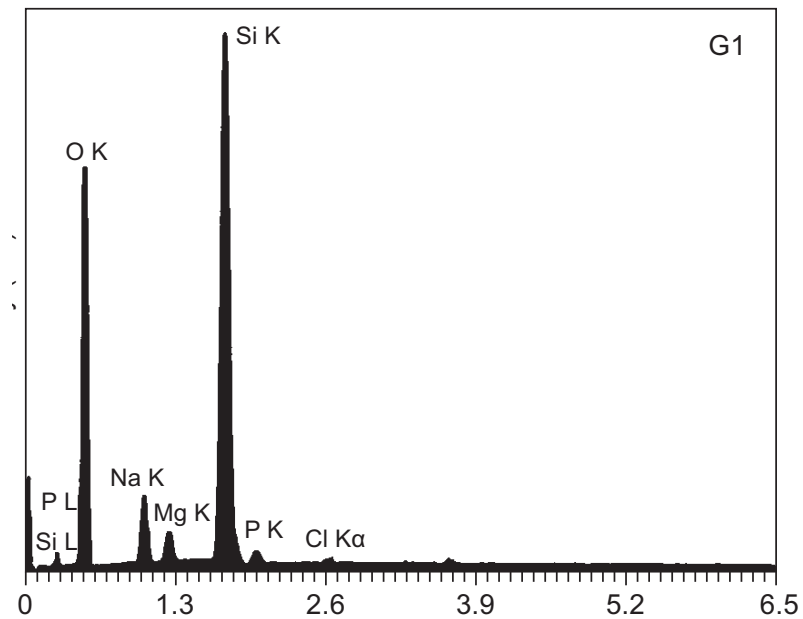

d)

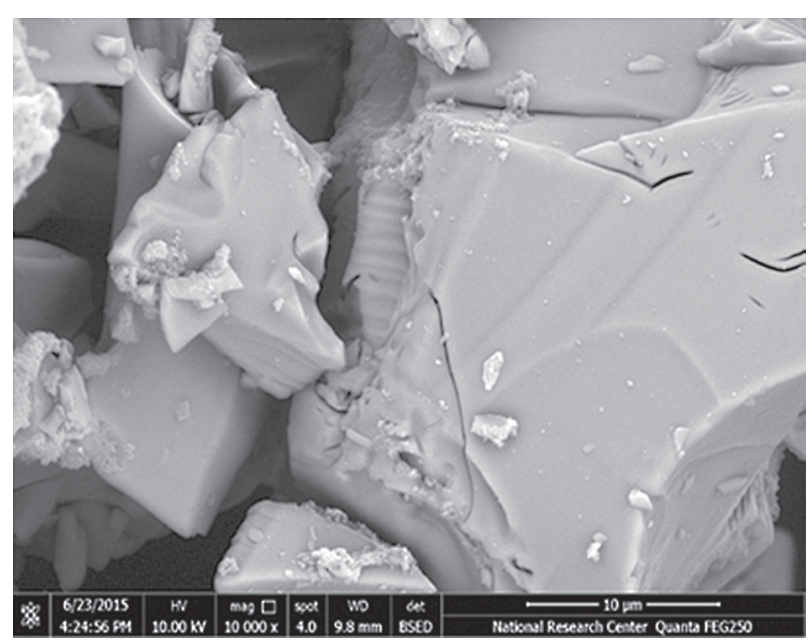

Figure 7. SEM Micrographs and EDX spectra of the glasses after immersion in SBF solution for 14 days.

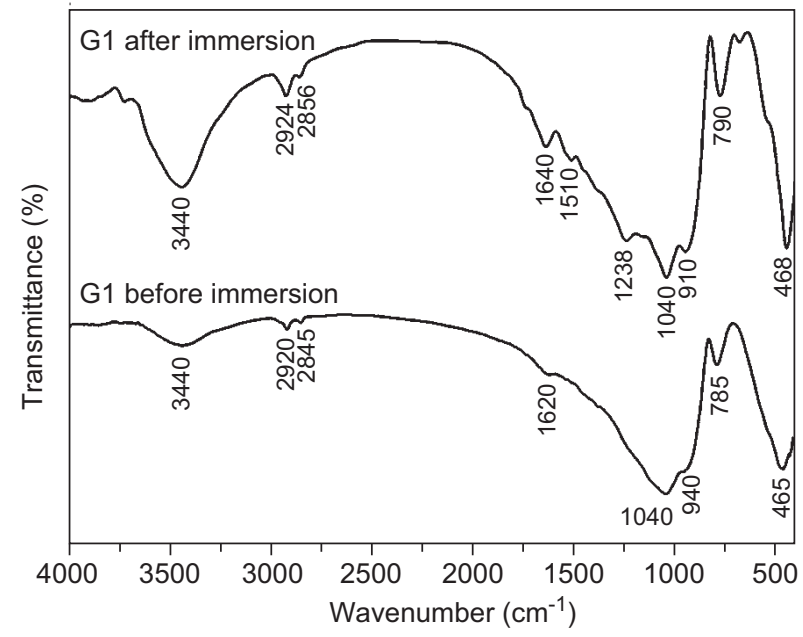

a)

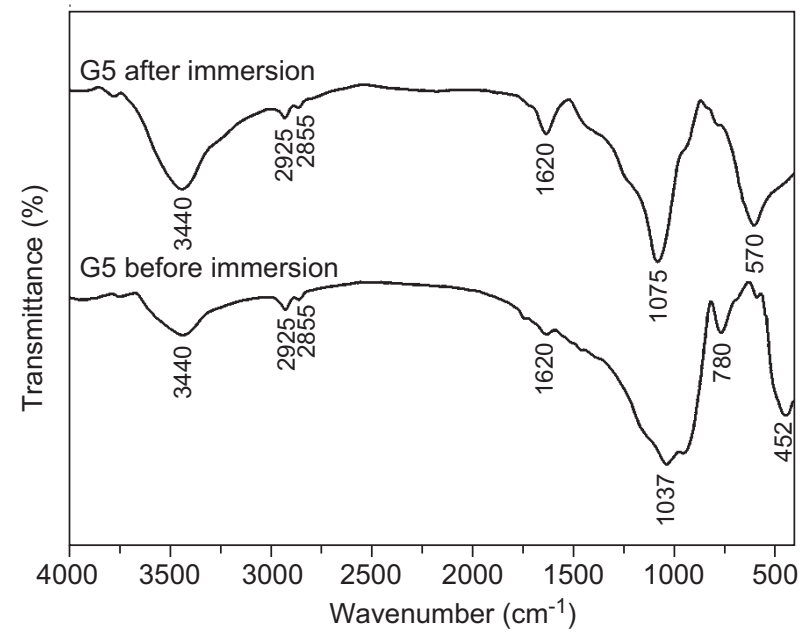

c)

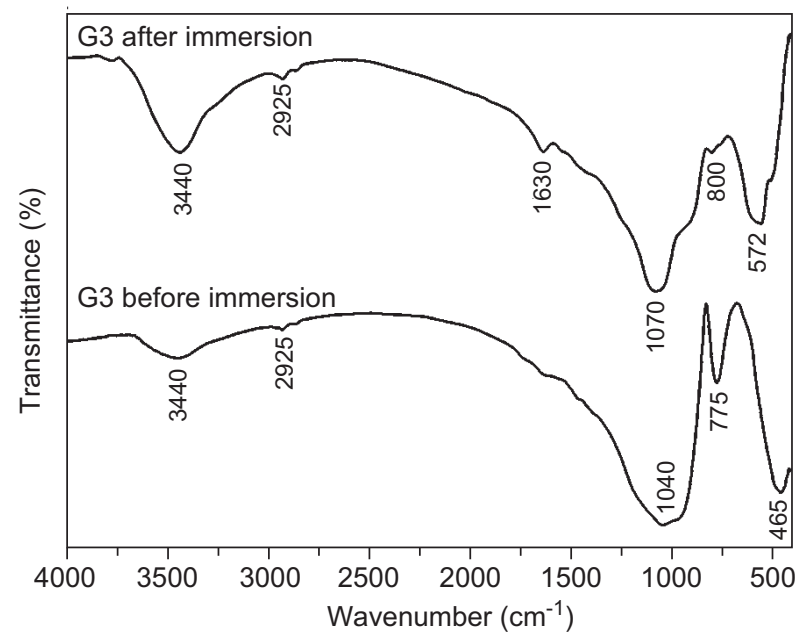

b)

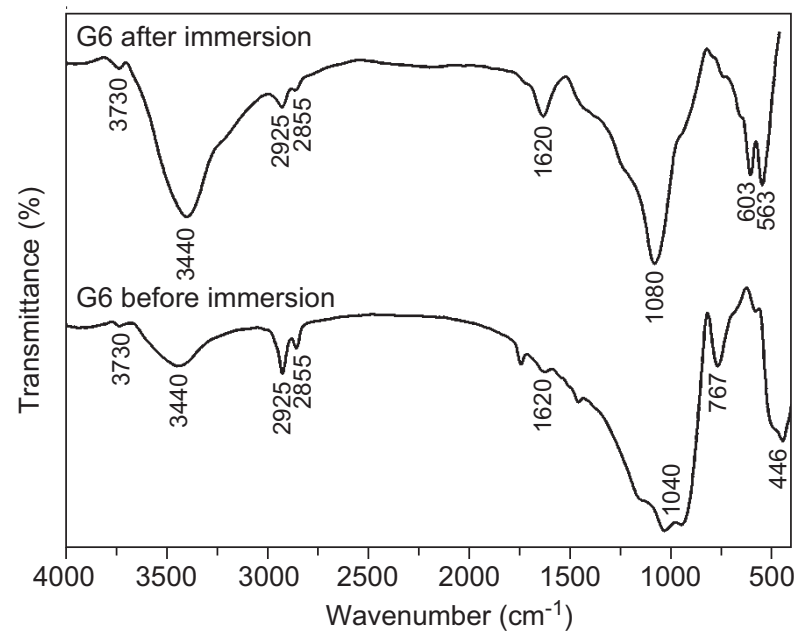

d)

Figure 8. FTIR spectra of glasses before and after immersion for 14 days in SBF solution. 
at $910 \mathrm{~cm}^{-1}$ [41] and the formation of $\mathrm{Si}-\mathrm{O}-\mathrm{Si}$ stretching peak at $1238 \mathrm{~cm}^{-1}$ [41]. The FTIR results refer to the formation of silanol to form a silica rich layer on the surface and there is no evidence on the formation of apatite layer.After soaking the glass samples $\mathrm{G}_{3} \mathrm{G}_{5}$ and $\mathrm{G}_{6}$ in SBF solution for 14 days, additional peaks with different intensities appears in the FTIR spectra around $570 \mathrm{~cm}^{-1}, 600 \mathrm{~cm}^{-1}$ and $1080 \mathrm{~cm}^{-1}$. The appearance of these peaks is characteristic for the formation of apatite layer [43].

\section{CONCLUSIONS}

Silicate glasses based on $\mathrm{Li}_{2} \mathrm{O}-\mathrm{MgO}-\mathrm{P}_{2} \mathrm{O}_{5}-\mathrm{SiO}_{2}$ system modified by alkali and alkaline oxides replacements have been successfully synthesized by the conventional melt technique. The properties of glasses like bulk density, microhardness, chemical resistance and in vitro bioactivity in simulated body fluid (SBF) were evaluated. The results obtained were provided good information about the glass structure, chemical and physical properties of the investigated glasses. The results of in vitro bioactivity test show that most of the glasses have capacity to form apatite layer after immersion in the SBF for 14 days. Therefore, it could be concluded that the investigated glass materials can be used in biomedical applications.

\section{REFERENCES}

1. Tai B.J., Bian Z., Jiang H., Greenspan D.C., Zhong J., Clark A.E., Du M.Q. (2006): Anti-gingivitis effect of a dentifrice containing bioactive glass (NovaMin) particulate. Journal of Clinical Periodontology, 33, 86-91. doi:10.1111/j.1600051X.2005.00876.x

2. Wallace K.E., Hill R.G., Pembroke J.T., Brown C.J., Hatton P.V. (1999): Influence of sodium oxide content on bioactive glass properties. Journal of Materials Science Materials in Medicine, 10, 697-701. doi:10.1023/A:1008910718446

3. Jones J.R. (2013): Review of bioactive glass: From Hench to hybrids. Acta Biomaterialia, 9, 4457-4486. doi:10.1016/j. actbio.2012.08.023

4. Huang W., Day D.E., Kittiratanapiboon K., Rahaman M.N. (2006): Kinetics and mechanisms of the conversion of silicate (45S5), borate, and borosilicate glasses to hydroxyl apatite in dilute phosphate solutions. Journal of Materials Science: Materials in Medicine, 17, 583-596. doi:10.1007/ s10856-006-9220-Z

5. Arcos D., Vallet-Regí M. (2010): Sol-gel silica-based biomaterials and bone tissue regeneration. Acta Biomaterialia, 6, 2874-2888. doi:10.1016/j.actbio.2010.02.012

6. Hench L.L., Splinter R.J., Allen W.C., Greenlee T.K. (1971): Bonding mechanisms at the interface of ceramic prosthetic materials. Journal of Biomedical Materials Research, 5, 117-141. doi:10.1002/jbm.820050611

7. Vogel M., Voigt C., Gross U.M., Müller-Mai C.M. (2001): In vivo comparison of bioactive glass particles in rabbits. Biomaterials, 22, 357-362. doi:10.1016/S0142-

\section{2(00)00191-5}

8. Lusvardi G., Zaffe D., Menabue L., Bertoldi C., Malavasi G., Consolo U. (2009): In vitro and in vivo behaviour of zinc-doped phosphosilicate glasses. Acta Biomaterialia, 5, 419-428. doi:10.1016/j.actbio.2008.07.007

9. Hesaraki S., Gholami M., Vazehrad S., Shahrabi S. (2010): The effect of $\mathrm{Sr}$ concentration on bioactivity and biocompatibility of sol-gel derived glasses based on $\mathrm{CaO}-\mathrm{SrO}-\mathrm{SiO}_{2}-\mathrm{P}_{2} \mathrm{O}_{5}$ quaternary system. Materials Science and Engineering: C, 30, 383-390. doi:10.1016/j. msec.2009.12.001

10. Habibovic P., Barralet J.E. (2011): Bioinorganics and biomaterials: Bone repair. Acta Biomaterialia, 7, 3013-3026. doi:10.1016/j.actbio.2011.03.027

11. Lieb J. (2007): Lithium and antidepressants: Stimulating immune function and preventing and reversing infection. Medical Hypotheses, 69, 8-11. doi:10.1016/j.mehy. 2006.12.005

12. Zamani A., Omrani G.R., Nasab M.M. (2009): Lithium's effect on bone mineral density. Bone, 44, 331-334. doi:10.1016/j.bone.2008.10.001

13. Rude R.K., Gruber H.E. (2004): Magnesium deficiency and osteoporosis: animal and human observations. The Journal of Nutritional Biochemistry, 15, 710-716. doi:10.1016/j. jnutbio.2004.08.001

14. Wiesmann H.P., Tkotz T., Joos U., Zierold K., Stratmann U., Szuwart T., Plate U., Höhling H.J. (1997): Magnesium in Newly Formed Dentin Mineral of Rat Incisor. Journal of Bone and Mineral Research, 12, 380-383. doi:10.1359/ jbmr.1997.12.3.380

15. Amighi J., Sabeti S., Schlager O., Mlekusch W., Exner M., Lalouschek W., Ahmadi R., Minar E., Schillinger M. (2004): Low serum magnesium predicts neurological events in patients with advanced atherosclerosis. Stroke, 35, 22-27. doi:10.1161/01.STR.0000105928.95124.1F

16. Balamurugan A., Balossier G., Michel J., Kannan S., Benhayoune H., Rebelo A.H., Ferreira J.M.: Sol Gel Derived $\mathrm{SiO}_{2}-\mathrm{CaO}-\mathrm{MgO}-\mathrm{P}_{2} \mathrm{O}_{5}$ Bioglass System-Preparation and In vitro Characterization. Journal of Biomedical Materials Research Part B: Applied Biomaterials, 83, 546-553 (2007). doi:10.1002/jbm.b.30827

17. Marie P.J., Ammann, P., Boivin, G., Rey, C.: Mechanisms of action and therapeutic potential of strontium in bone. Calcified Tissue International, 69, 121-129 (2001). doi:10.1007/s002230010055

18. Marie P.J. (2005): Strontium ranelate: a novel mode of action optimizing bone formation and resorption. Osteoporosis International, 16, S7-S10. doi:10.1007/s00198004-1753-8

19. Salama S.N., Salman S.M. (1994): Chemical stability of some manganese glass- ceramics. Materials Chemistry and Physics, 37, 338-343. doi:10.1016/0254-0584(94)90172-4

20. Salman S.M., Salama S.N., Abo-Mosallam H.A. (2015): Crystallization of pyroxene phases and physico-chemical properties of glass-ceramics based on $\mathrm{Li}_{2} \mathrm{O}_{-}-\mathrm{Cr}_{2} \mathrm{O}_{3}-\mathrm{SiO}_{2}$ eutectic glass system. Materials Chemistry and Physics, 149-150,385-392.doi:10.1016/j.matchemphys.2014.10.033

21. Kokubo T., Kushitani H., Sakka S., Kitsugi T., Yamamuro T. (1990): Solution able to reproduce in vivo surface-structure changes in bioactive glass-ceramics A-W, Journal of Biomedial Materials Research, 24, 721-734. doi:10.1002/jbm. 820240607

22. Li Y., Liang K., Cao J., Xu B. (2010): Spectroscopy and 
structural state of $\mathrm{V}^{4+}$ ions in lithium aluminosilicate glass and glass-ceramics. Journal of Non-Crystalline Solids, 356, 502-508. doi:10.1016/j.jnoncrysol.2009.12.018

23. Mahdy E.A., Ibrahim S. (2012): Influence of $\mathrm{Y}_{2} \mathrm{O}_{3}$ on the structure and properties of calcium magnesium aluminosilicate glasses, Journal of Molecular Structure, 1027, 81-86. doi:10.1016/j.molstruc.2012.05.055

24. Mozafari, M., Moztarzadeh F., Rabiee M., Azami M., Tahriri M., Moztarzadeh, Z., Nezafati N. (2010): Development of macroporous nanocomposite scaffolds of gelatin/bioactive glass prepared through layer solvent casting combined with lamination technique for bone tissue engineering. Ceramics International, 36, 2431-2439. doi:10.1016/j. ceramint.2010.07.010

25. Branda F., Arcobello-Varlese F., Costantini A., Luciani G. (2002): Effect of the substitution of $\mathrm{M}_{2} \mathrm{O}_{3}(\mathrm{M}=\mathrm{La}, \mathrm{Y}$, In, $\mathrm{Ga}, \mathrm{Al}$ ) for $\mathrm{CaO}$ on the bioactivity of $2.5 \mathrm{CaO} \cdot 2 \mathrm{SiO}_{2}$ glass. Biomaterials, 23, 711-716. doi:10.1016/S01429612(01)00173-9

26. Mi-tang W., Jin-shu C., Mei L., Feng H. (2011): Structure and properties of soda lime silicate glass doped with rare earth. Physica B, 406, 187-191. doi:10.1016/j.physb.2010. 10.040

27. Serra J., González P., Liste S., Serra C., Chiussi S., León B., Pérez-Amor M., Ylänen H.O., Hupa M. (2003): FTIR and XPS studies of bioactive silica based glasses. Journal of Non-Crystalline Solids, 332, 20-27. doi:10.1016/j. jnoncrysol.2003.09.013

28. Kim C.Y., Clark A.E., Hench L.L. (1989): Early stages of calcium phosphate layer formation in bioglasses. Journal of Non-Crystalline Solids, 113, 195-202. doi:10.1016/00223093(89)90011-2

29. Xiang Y., Du, J., Skinner L.B., Benmore C.J., Wren A.W., Boyd D.J., Towler M.R. (2013): Structure and diffusion of $\mathrm{ZnO}-\mathrm{SrO}-\mathrm{CaO}-\mathrm{Na}_{2} \mathrm{O}-\mathrm{SiO}_{2}$ bioactive glasses: A combined high energy X-ray diffraction and molecular dynamics simulations study. RSC Advances, 3, 5966-5978. doi:10.1039/C3RA23231J

30. Rajendran V., Palanivelu N., Modak D.K., Chaudhuri B.K. (2000): Ultrasonic Investigation on Ferroelectric $\mathrm{BaTiO}_{3}$ Doped $80 \mathrm{~V}_{2} \mathrm{O}_{5}-20 \mathrm{PbO}$ Oxide Glasses. Physical Status Solidi A, 80, 467-477. doi:10.1002/1521-396X (200008)180:2<467::AID-PSSA467>3.0.CO;2-5

31. Jha P.K., Pandey O.P., Singh K. (2015): Structure and crystallization kinetics of $\mathrm{Li}_{2} \mathrm{O}$ modified sodium-phosphate glasses. Journal of Molecular Structure, 1094, 174-182. doi:10.1016/j.molstruc.2015.03.066

23. Du J., Xiang Y. (2012): Effect of strontium substitution on the structure, ionic diffusion and dynamic properties of 45S5 Bioactive glasses. Journal of Non-Crystalline Solids, 358, 1059-1071. doi:10.1016/j.jnoncrysol.2011.12.114

33. Brown G.E., Farges F., Calas G. (1995): X-ray scattering and X-ray spectroscopy studies of silicate melts. Reviews in Mineralogy and Geochemistry, 32, 317-410.

34. Shelby J.E. (2005). Introduction to Glass Science and Technology, $2^{\text {nd }}$ ed., the Royal Society of Chemistry.

35. Hill R.G., Stamboulis A., Law R.V., Clifford A., Towler M.R., Crowley C. (2004): The influence of strontium substitution in flouroapatite glasses and glass-ceramics. Journal of Non-Crystalline Solids, 336, 223-229. doi:10.1016/j.jnoncrysol.2004.02.005

36. Paul A. (1982). Chemistry of Glasses. Chapman and Hall Ltd.

37. Cotton F. A. , Wilkinson G. , Murillo C. A., Bochmann M. (1999). Advanced Inorganic Chemistry. $6^{\text {th }}$ ed., Wiley interscience.

38. Avramov I., Vassilev Ts., Penkov I. (2005): The glass transition temperature of silicate and borate glasses. Journal of Non-Crystalline Solids, 351, 472-476. doi:10.1016/j. jnoncrysol.2005.01.044

39. Oliveira J.M., Correia R.N., Fernandes M.H. (1995): Surface modification of a glass and a glass-ceramic of the $\mathrm{MgO}-3 \mathrm{CaO} \cdot \mathrm{P}_{2} \mathrm{O}_{5}-\mathrm{SiO}_{2}$ system in a simulated body fluid. Biomaterials, 16, 849-854. doi:10.1016/0142-9612 (95)94146-C

40. Lopez-Esteban S., Saiz E., Fujino S., Oku T., Suganuma K., Tomsia A.P. (2003): Bioactive glass coatings for orthopedic metallic implants. Journal of the European Ceramic Society, 23, 2921-2930. doi:10.1016/S0955-2219(03)00303-0

41. Peitl O., Zanotto E.D., Hench L.L. (2001): Highly bioactive $\mathrm{P}_{2} \mathrm{O}_{5}-\mathrm{Na}_{2} \mathrm{O}-\mathrm{CaO}-\mathrm{SiO}_{2}$ glass-ceramics. Journal of NonCrystalline Solids, 292, 115-126. doi:10.1016/S0022-3093 (01)00822-5

42. Hench L.L. (1991): Bioceramics: From concept to clinic. Journal of the American Ceramic Society, 74, 1487-1510. doi:10.1111/j.1151-2916.1991.tb07132.x

43. Brauer D.S., Karpukhina N., O’Donnell M.D., Law R.V., Hill R.G. (2010): Fluoride-containing bioactive glasses: Effect of glass design and structure on degradation, $\mathrm{pH}$ and apatite formation in simulated body fluid. Acta Biomaterialia, 6, 3275-3282. doi:10.1016/j.actbio.2010.01.043 